\title{
Interaction of landscape space and indoors in architecture of the open-air concert hall "Mītava"
}

\author{
Aija Grietēna, Latvia University of Life Sciences and Technologies, Latvia
}

\begin{abstract}
In the search for balancing factors in the art of environmental design between architecture, landscape architecture, and interiors needed to improve interdisciplinary collaborative planning and enhance the psycho-emotional quality of the environment, the study of landscape space-indoor interaction through comparative analysis and inductive reference is continued. On the Latvian scale, the new, 21st-century technological capabilities in the design and production of wooden structures in the architecture of the open air concert hall "Mītava", constructed in 2019 on Pasta Island. The importance of the structure on the Baltic scale is emphasized by the unique design, which resembles a shell washed on the bank of the Lielupe River, large $(<60 \mathrm{~m})$ arched timber continuous roof structures and high acoustic characteristics. Original building structures have opened up new opportunities for interaction between landscape space and indoor space, creating a broad, spatial synthesis. The realization of an artistically stylistic concept in the open-air concert hall "Mītava", which is subordinated to the existing landscape space and supplemented with appropriate greenery, is considered a valuable contribution to the urban environment. The specific case study analyzed in detail underlines the importance of successful interdisciplinary collaboration in the harmonious interaction between landscape space and indoor.
\end{abstract}

Keywords: landscape architecture, architecture, interaction of landscape space and indoors

\section{Introduction}

At the Latvian level, as in the global context, increasing attention is being paid to the balance in all its aspects, as evidenced by one of the most important documents of recent years in the field of architectural policy - the Davos Declaration signed at the 2018 World Economic Forum. This document manifests the concept and principles of Baukultur, whose mission is to create and maintain a high quality built environment that will be passed down to future generations [2]. The purpose of Latvian Architecture Policy, which is in line with the concept and principles of the built environment culture as defined in the Davos Declaration, is to create conditions for qualitative design and sustainability of the living space of the individual and society based on high-quality architecture [1].

In the complex construction process of today, environmental makers are striving to stay positive in the face of the growing need for deeper interdisciplinary collaborative planning, and we all as environmental users for environmental integrity and harmony $[4 ; 11 ; 12 ; 13]$. The actuality of harmonious landscape space and indoor interaction is underlined by the rapidly changing role of architecture, high involvement of environmental users in the processes of creating a public environment and new technological possibilities today. This is not only facilitated by the increasing use of transparent, wide exterior glazed panels in architecture, which visually blends the landscape space with the interior through illusionary and plastic architectural forms [4; 5], but also the direct, extensive connection of landscaping space and interior without glass, which is the result of 21 st-century technological capabilities in the design and manufacture of wooden structures. "Thanks to its enormous achievements in engineering, wood is rapidly regaining its position in the global construction market," said A. Domkin (A. Domkins), Director of the "Forest and Wood Products Research and Development Institute" [9]. Original, large-span, curved, glued-in wooden structures open up wide and long-awaited opportunities for Latvian architects to creativity, which materializes in modern architecture and more ambitious interaction of landscape spaces and interiors. Maximally open space without glazed planes, partially covered indoor visual communication between landscape space and indoor expands through sound, smell, and tactile capabilities. The pattern of landscape space and indoor interaction today consists of an endless combination of different factors. The most important visual factors are divided into four psychoemotional criteria that help to assess composition and proportions, colour, light and shadow impacted by sunlight, visual accents by chiaroscuro play and visual merging of indoors and landscape space. The fifth criterion are architectural forms in landscape $[4 ; 5]$. Pooling the information obtained in two directions (looking from the landscape to the indoor) and vice versa provides a more complete assessment of the interaction.

At the beginning of the 21 st century, the Latvian landscape space has become richer with several expressive concert halls, which are very important 


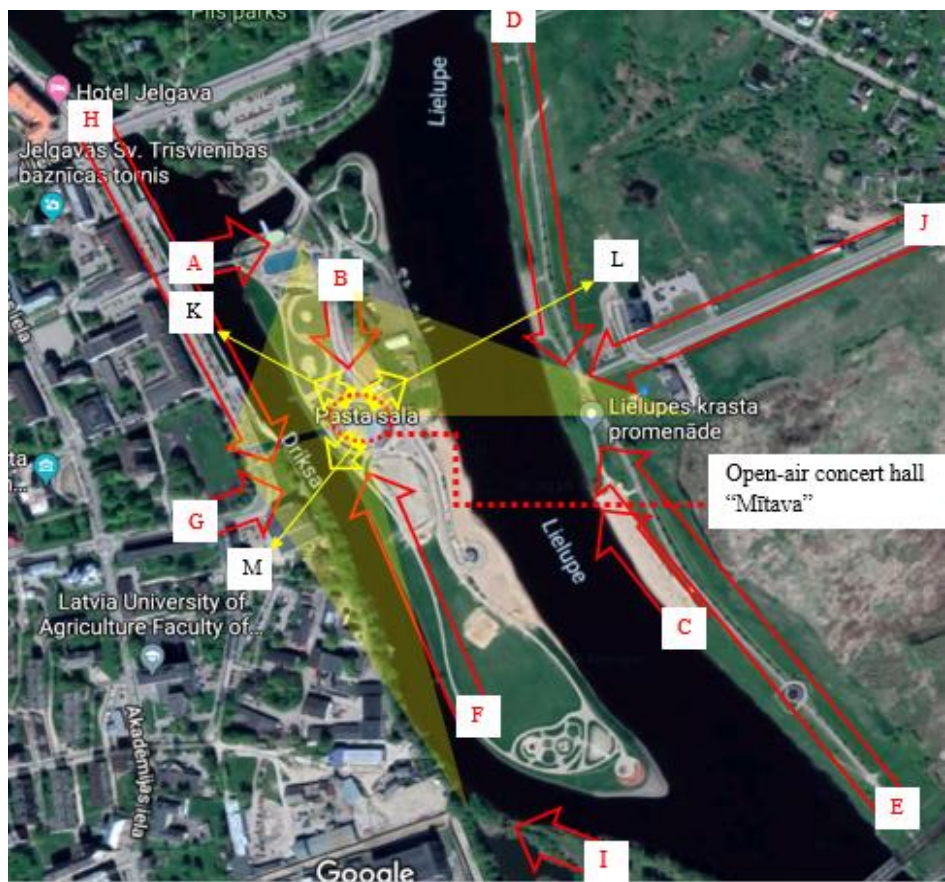

$A ; B ; C ; D ; E ; F ; G ; H ; I ; J ; K ; L ; M-$ key viewpoints
to the concert hall

Fig. 1. Open-air concert hall "Mitava" in the landscape area with view lines and points [graph created by the author on googlemap, 2019]

for the decentralization of cultural processes in the country. In the summer of 2019, Jelgava City also acquired the long-awaited and vital for the cultural life, the open-air concert hall "Mìtava" (Fig. 1), which was built on the Pasta island.

Aim of the research - to identify the contributing factors for harmonious interaction of landscape space and indoors in the art of environment formation in Latvia (in the example of the open-air concert hall "Mìtava").

Tasks of the research.

1. To evaluate the interaction of landscape space and indoors in architecture.

2. To formulate the factors of harmonious interaction of landscape space and indoors in the art of environment formation.

The theoretical and practical significance of the work is the formation of psycho-emotionally more harmonious and high-quality spatial environment in Latvia, thraugh better coopertion between architects, landscape architects and interior design specialist.

\section{Materials and Methods}

Interaction of landscape space and indoors in architecture of the open-air concert hall "Mìtava" in Latvia. The visual research was conducted in September-November 2019 when the author became the user of the research object and took photos. Reserch methods: comporative analysis method (photographic fixation capture, analysis of interaction factors according to uniform criteria) and inductive cognitive method (to generalize the results).
The application of the comparative method in summarizing information for the research

The criteria for evaluation of psycho-emotional interaction of indoors and landscape space:

- evaluation of spatial composition and proportions of glazed surfaces versus the nonglazed part;

- evaluation of compositional application of colour, light and shadow impacted by sunlight;

- evaluation of the usage of visual accents created by chiaroscuro play;

- evaluation of the visual merging of indoors and landscape space.

Evaluation of architectural forms in landscape space.

\section{Results and Discussion}

Interaction of landscape space and indoors under the influence of visual perception

Open-air concert hall "Mītava" in Jelgava:

- Address - Pasta sala, Jelgava, Latvia (Figure 1);

- Implementation - 2019;

- Architecture - SIA "Projektu birojs Grietēns un Kagainis", Vents Grietens (Vents Grietèns), landscape architecture - Marta Tabaka (Marta Tabaka); constructions - Peter Supe (Pēteris Supe);

- Realization - IBK (SIA "Igate Būve" un SIA "Kvadrum"), developer and manufacturer of curved wooden constructions - SIA "IKTK" in cooperation with "MeKA").

The Mitava open-air concert hall is the largest of its kind in the Baltic States, with wooden structures 
using approximately 530 cubic meters of wood. The largest total span is about 60 meters, which is also a new record in the history of Latvian construction. Continuous beams have a span of 20 to 30 meters each - this is the original work of architects, designers, manufacturer of building structures and builder [6]. The unique roof construction, which resembles a shell washed off the Lielupe River, uses a high-quality roof membrane solution.

The membrane was manufactured, supplied and installed by "Canobbio Textile Engineering" $[3 ; 6]$. Main view lines and points when perceptualizing the interaction of landscape space and indoors of object architecture in a direction from landscape space and vice versa - in direction from building's indoors towards landscape space (Figure 1; TABLE 1;2).

Context of natural foundation and greenery in Interaction of landscape space and indoors

The Concert Hall is located on the Pasta Island in the city center between the River Lielupe and the River Driksa. The island's natural backdrop, which is surrounded by specific rivers, underwent its revival in 2014 with a major reconstruction. Reconstructed Pasta Island, recognized as the best public outdoor facility in Latvia in 2014. This is evidenced by the victory in the nomination "Public Outdoor Object" of the Latvian Construction Awards 2014 [10]. In the competition "Sustainability in Architecture, Construction, Design 2019" the 2nd place in the Latvian scale was nominated in the nomination "Sustainable Public Outer Space 2019". The designers are "Dianas Zalanes Project Office" and the "Grietens and Kagainis Project Office" [8].

As a result of the reconstruction, significant changes have affected the greenery and the natural base raised to avoid flood risks from the Lielupe in the spring. Throughout history, Jelgava (Mithava) has grown around a much larger island, divided into smaller canals by artificial means. For example, the famous Jelgava Castle is built on Castle Island and only a small canal separates it from Pasta Island. Historically, the island complex is considered to be the city center, but nowadays it is an informal center. Castle Island supports two bridges connecting both sides of Jelgava. A few years later, a new open-air concert hall called "Mītava" was opened on the wellmaintained Pasta Island. The specific factors make it possible to claim that the concert hall was created in the heart of the city, underlining its importance geographically. In line with existing and prospective major environmental user mobility habits, key viewpoints to the concert hall $(\mathrm{A} ; \mathrm{B} ; \mathrm{C} ; \mathrm{D} ; \mathrm{E} ; \mathrm{F} ; \mathrm{G}$; $\mathrm{H} ; \mathrm{I} ; \mathrm{J} ; \mathrm{K} ; \mathrm{L} ; \mathrm{M})$ have been selected,

which are further analysed in the study. The new greenery on Pasta Island, Cakste (Čakstes) Boulevard and Promenade has not yet reached maturity in size, which also influences the interplay between the architecture, indoor and landscape space of the investigated concert hall, putting it in perspective (Figure 1; TABLE 3; 4). preserve old tree plantations.

Psycho-emotional nature of spatial synthesis under the influence of natural and artificial light distribution.

Analyzing the importance of natural and artificial lighting in the interaction of landscape space and indoor space in the architecture of the open-air concert hall "Mìtava", it is necessary to emphasize the wide variability of external conditions in the

rhythms of the day and season in Latvia. The long twilight hours of day and night alternation, the four seasons with different lighting and the changing meteorological weather affect only one aspect. In addition, artificial lighting produces a complex set of influencing factors (Figure1; TABLE 5; 6).

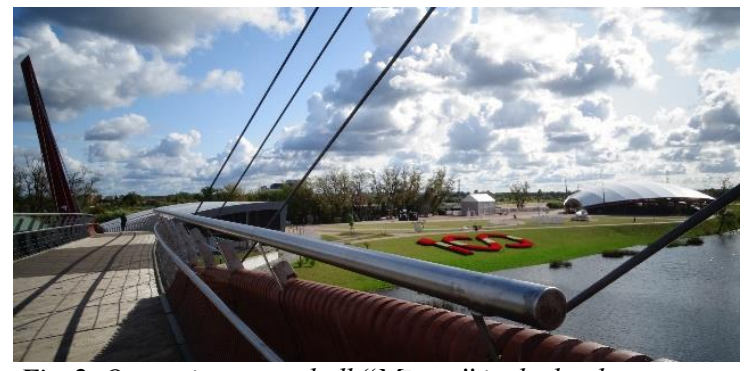

Fig. 2. Open-air concert hall "Mitava" in the landscape area, viewing from the pedestrian bridge "Mĩtava" (View line A) [photo created by the author, 2019]

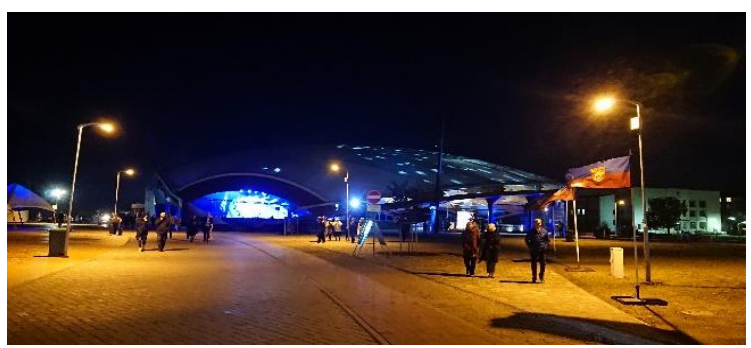

Fig. 3. Open-air concert hall "Mîtava" in the landscape area (View line B) [photo created by the author, 2019]

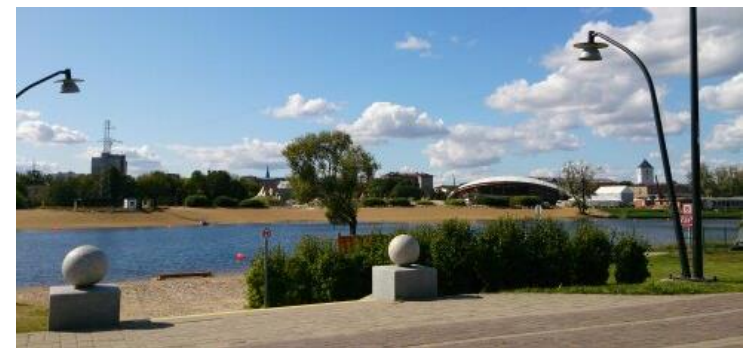

Fig. 4. Open-air concert hall "Mîtava" in the landscape area (View line C) [photo created by the author, 2019]

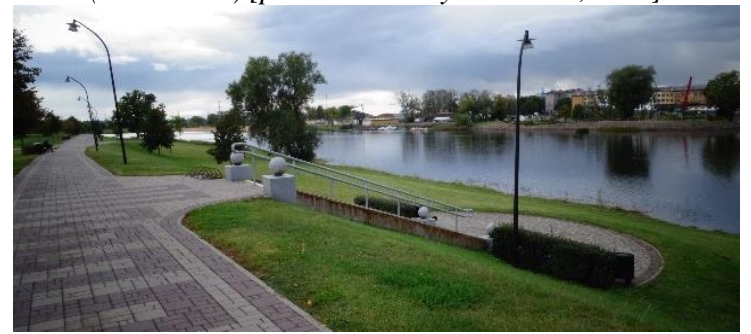

Fig. 5. Open-air concert hall "Mîtava" in the landscape area (View line D) [photo created by the author, 2019] 


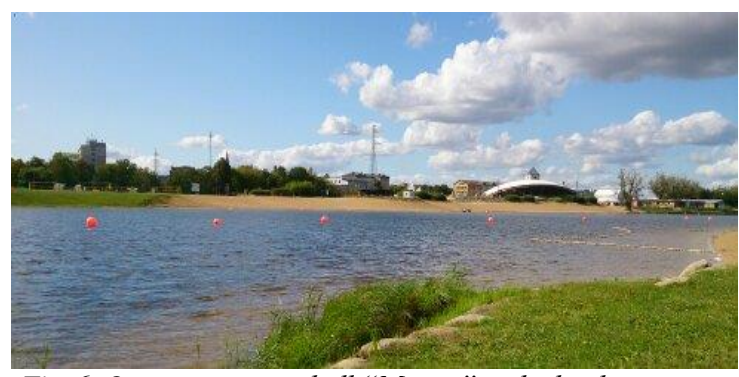

Fig. 6. Open-air concert hall "Mîtava" in the landscape area (View line E) [photo created by the author, 2019]

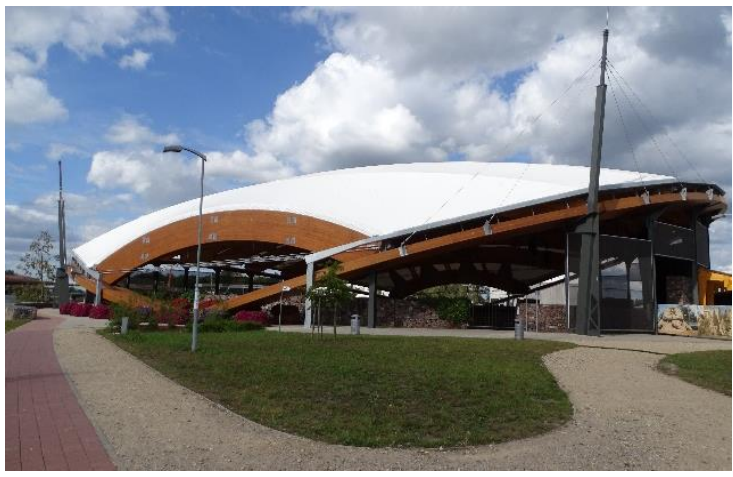

Fig. 7. Open-air concert hall "Mītava"

in the landscape area (View line $\boldsymbol{F}$ )

[photo created by the author, 2019]

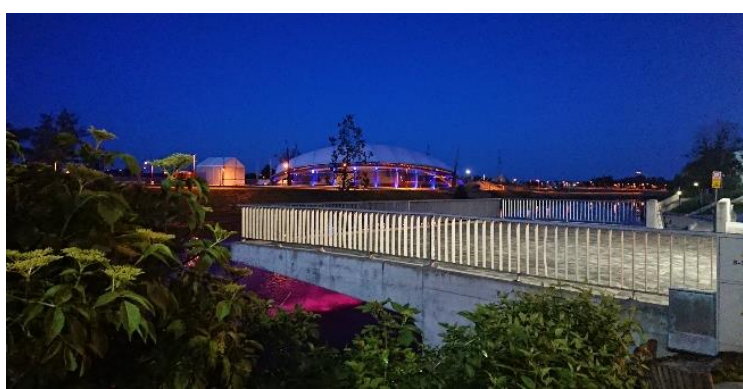

Fig. 8. Open-air concert hall "Mîtava" in the landscape area (View line $\boldsymbol{G}$ ) [photo created by the author, 2019]

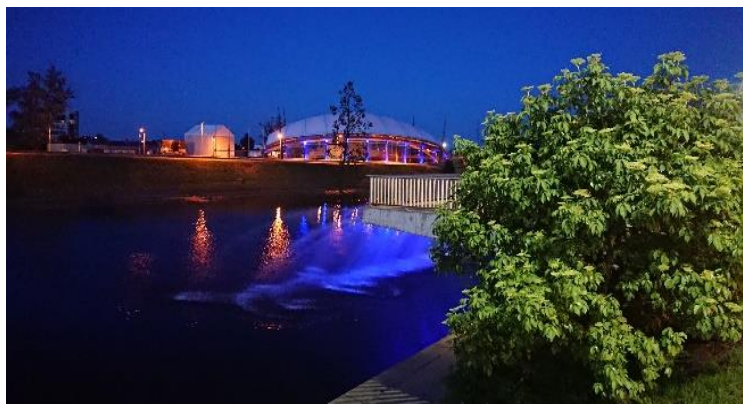

Fig. 9. Open-air concert hall "Mittava" in the landscape area (View line $\boldsymbol{H})$ [photo created by the author, 2019]

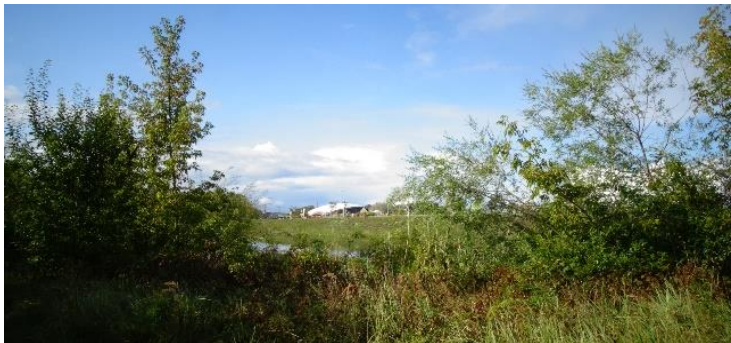

Fig. 10. Open-air concert hall "Mîtava" in the landscape area (View line I) [photo created by the author, 2019]

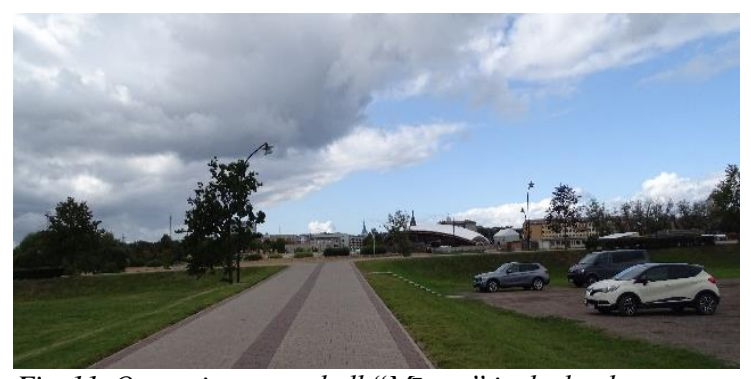

Fig. 11. Open-air concert hall "Mitava" in the landscape area (View line J) [photo created by the author, 2019]

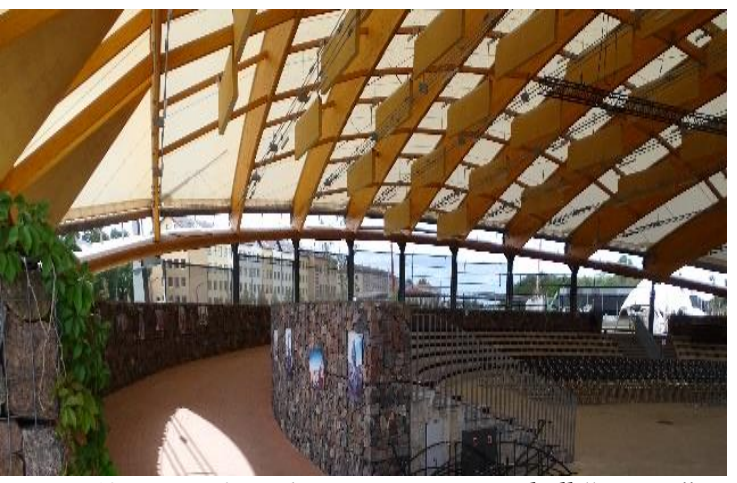

Fig. 12. A view from the Open-air concert hall "Mittava" indoor of the urban landscape (View point $\boldsymbol{K}$ ) [photo created by the author, 2019]

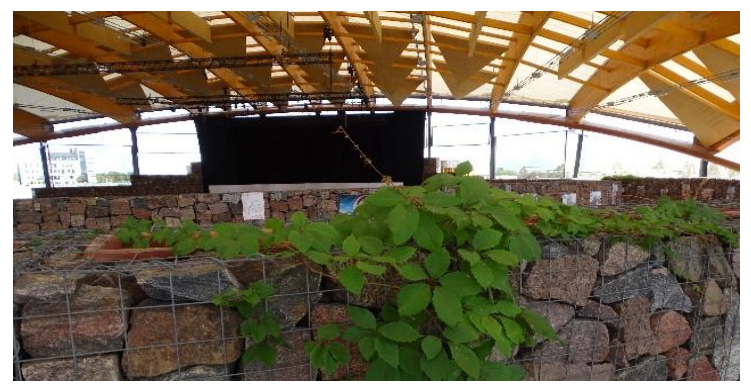

Fig.13. Open-air concert hall "Mittava" indoor of the urban landscape (View line L) [photo created by the author, 2019]

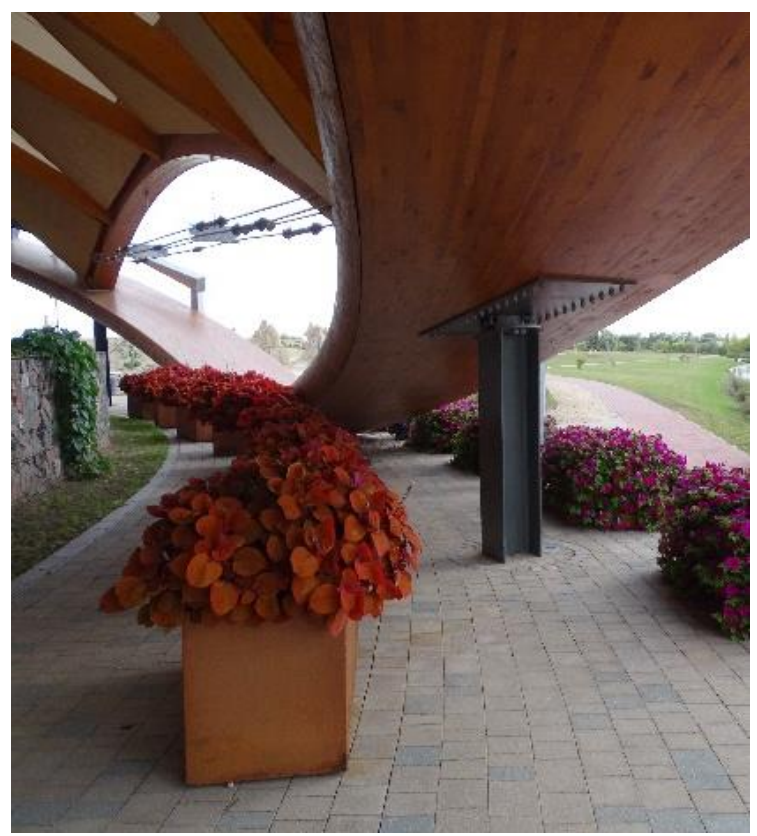

Fig. 14. A view from the Open-air concert hall "Mittava" indoor of the urban landscape (View point $\boldsymbol{M}$ ) [photo created by the author, 2019] 
Interaction of landscape space and indoors under the influence of visual perception

View lines from landscape space to architecture [created by the author, 2019]

\begin{tabular}{|c|c|c|c|c|}
\hline 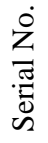 & $\begin{array}{c}\text { View marking and } \\
\text { direction }\end{array}$ & 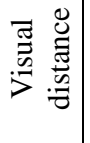 & 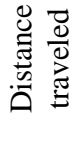 & Description of results \\
\hline 1. & $\begin{array}{l}\text { View line A } \\
\text { (Fig. 2) is the highest } \\
\text { view line as it passes } \\
\text { through the pedestrian } \\
\text { bridge "Mìtava", from } \\
\text { the Driksa`s shoreline to } \\
\text { Pasta Island to the } \\
\text { skating rink. }\end{array}$ & 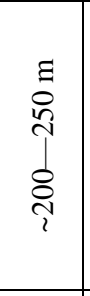 & $\begin{array}{c}\Xi \\
\stackrel{\Xi}{1} \\
i\end{array}$ & $\begin{array}{l}\text { The elevation of the pedestrian bridge shows the ambitious volume of } \\
\text { the concert hall "Mitava" in the cityscape space with its proportions } \\
\text { and milk-white, light-reflecting and translucent roof membrane. } \\
\text { The building resembles a shell in a stylized way, organically } \\
\text { inscribing itself on the Pasta Island and adjacent landscaping space. } \\
\text { The presence of the Driksa river, which opens up a wide range of } \\
\text { visually spatial accessibility, accentuates the size of the building. } \\
\text { Open-air facade shields cover the concert hall's interior view. }\end{array}$ \\
\hline 2. & $\begin{array}{l}\text { View line B } \\
\text { (Fig. 3), following } \\
\text { south on the main } \\
\text { representative path of } \\
\text { Pasta Island from the } \\
\text { children's playground in } \\
\text { the north to the } \\
\text { concert hall. }\end{array}$ & $\begin{array}{l}i \\
i \\
i \\
i\end{array}$ & $\frac{8}{1}$ & $\begin{array}{l}\text { Reveals the dominance of the volume and color solution of the } \\
\text { concert hall in the landscape space. The harmonious view is } \\
\text { obstructed by the large temporary tent, which is permanently located } \\
\text { on the left side of the concert hall. Similar color solutions merge the } \\
\text { two buildings into one, creating a visually disharmonious overall } \\
\text { volume. Disharmony is enhanced by the degenerate territory adjacent } \\
\text { to the concert hall, which joins the left bank of the Lielupe river. } \\
\text { The concert hall's interior delicately communicates with the } \\
\text { landscape when the entrance shields are raised. }\end{array}$ \\
\hline 3. & $\begin{array}{l}\text { View line C } \\
\text { (Fig. 4) is the lowest } \\
\text { line of view, moving } \\
\text { from the lawn along the } \\
\text { sandy beach on the right } \\
\text { bank of the Lielupe to } \\
\text { the lawn. }\end{array}$ & 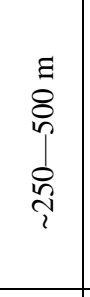 & 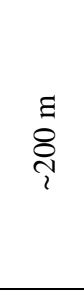 & $\begin{array}{l}\text { The volume of the concert hall is recorded proportionally and } \\
\text { harmoniously in the landscape space, the city building with separate } \\
\text { peaks in the background, which gives the landscape dynamics. At the } \\
\text { forefront of the Pasta Island, the degraded area on the left bank of the } \\
\text { Lielupe, with its proportions, severely undermines the visual } \\
\text { aesthetics of the landscape. Reinforced by a temporary large-sized } \\
\text { tent that stands next to the concert hall for a long time. The interior of } \\
\text { the concert hall is not visible due to the distance. }\end{array}$ \\
\hline 4. & $\begin{array}{l}\text { View line D } \\
\text { (Fig. 5), moving south- } \\
\text { east on Lielupes Street } \\
\text { along the promenade to } \\
\text { Peldu Street. }\end{array}$ & $\begin{array}{l}E \\
8 \\
\stackrel{2}{i n} \\
1 \\
0 \\
i \\
i\end{array}$ & $\begin{array}{l}\Xi \\
\stackrel{9}{7} \\
\stackrel{7}{i}\end{array}$ & $\begin{array}{l}\text { The concert hall overlooking the Lielupe river opens only behind the } \\
\text { degraded area of the Pasta island, which is in the foreground, } \\
\text { significantly disturbing the visual aesthetic perception of the } \\
\text { landscape space. The interior of the concert hall is not visible due } \\
\text { to the distance. }\end{array}$ \\
\hline 5. & $\begin{array}{l}\text { View line } \mathbf{E} \\
\text { (Fig. 6), moving south- } \\
\text { east from the railway } \\
\text { bridge along the } \\
\text { promenade to Peldu } \\
\text { Street. }\end{array}$ & 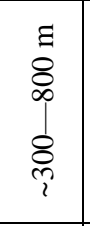 & $\begin{array}{l}\Xi \\
8 \\
8 \\
i\end{array}$ & $\begin{array}{l}\text { There is a harmonious scenery of Lielupe and Pasta Island with } \\
\text { a balanced accent in the center of the island thanks to the size and } \\
\text { proportions of the concert hall. City building in the background. } \\
\text { So far, brownfields have a negative impact on the quality of the } \\
\text { environment. The interior of the concert hall is not visible due to the } \\
\text { distance. }\end{array}$ \\
\hline 6. & $\begin{array}{l}\text { View line F } \\
\text { (Fig. 7), moving } \\
\text { northwest along the } \\
\text { main island of Pasta } \\
\text { Island along the Driksa } \\
\text { River to the Concert } \\
\text { Hall. }\end{array}$ & 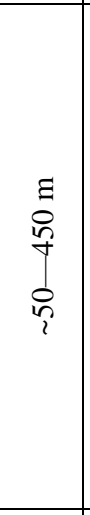 & $\begin{array}{l}\Xi \\
8 \\
\stackrel{8}{+} \\
i\end{array}$ & $\begin{array}{l}\text { On the view line, behind the voluminous formations of sand } \\
\text { sculptures, the light building volume of the concert hall reads partly, } \\
\text { in the background, the } 4-5 \text {-story building of Jelgava City on the left } \\
\text { shore of Driksa, the dominant of the Trinity Church Tower, and the } \\
\text { expressively curved pedestrian bridge "Mitava" over the river. } \\
\text { Visual balanced landscape space. As they move closer, a part of the } \\
\text { concert hall adjacent to the Driksa river is revealed. On the left side } \\
\text { of the drivel, looking back, an unkempt, degraded environment with } \\
\text { aggressive building volumes of Jelgava Prison, swimming pool, etc. } \\
\text { in arbitrarily grown plants. The interior of the concert hall is visible } \\
\text { as it approaches the building and organically moves from the } \\
\text { landscape room into the interior, thanks to selected stone materials } \\
\text { and plantings that visually merge the spaces and make the entrance } \\
\text { gradual and harmonious. }\end{array}$ \\
\hline 7. & $\begin{array}{l}\text { View line G } \\
\text { (Fig. 8), moving east on } \\
\text { Raina (Raina) Street } \\
\text { from the Forest Faculty } \\
\text { building to the Driksa } \\
\text { River. }\end{array}$ & 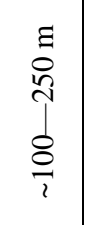 & $\begin{array}{l}\Xi \\
\stackrel{\Xi}{2} \\
\frac{1}{1}\end{array}$ & 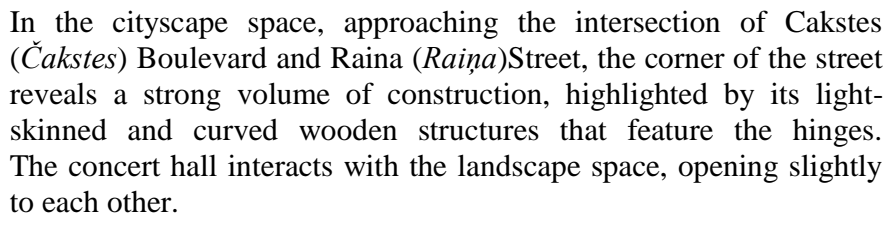 \\
\hline
\end{tabular}




\begin{tabular}{|c|c|c|c|c|}
\hline 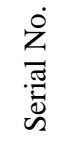 & $\begin{array}{l}\text { View marking and } \\
\text { direction }\end{array}$ & 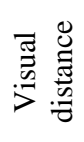 & 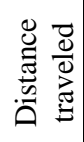 & Description of results \\
\hline 8. & $\begin{array}{l}\text { View line } \mathbf{H} \\
\text { (Fig. 9), following } \\
\text { J. Cakste ( } \text { Čakste) } \\
\text { Boulevard from } \\
\text { Lielā Street in a } \\
\text { south-east direction to } \\
\text { Raina (Raina) Street. }\end{array}$ & $\begin{array}{l}\Xi \\
0 \\
\vdots \\
+ \\
8 \\
0 \\
1\end{array}$ & $\begin{array}{l}\Xi \\
8 \\
0 \\
i \\
i\end{array}$ & $\begin{array}{l}\text { From the intersection of Lielä Street you can see a dynamically } \\
\text { shaped landscape space with two accents: the pedestrian bridge } \\
\text { "Mítava" and the open-air concert hall "Mìtava", which are in visual } \\
\text { balance with each other underlining each other. It is united by } \\
\text { a similar form of language, expressed in curved forms and cable } \\
\text { structures. Moving past the pedestrian bridge, the spectacular } \\
\text { proportions of the concert hall and the play of the lights in the light } \\
\text { roof covering resonate with the sky and the water. The interior of the } \\
\text { concert hall is not visually visible due to the open shields } \\
\text { on the facade. }\end{array}$ \\
\hline 9. & $\begin{array}{l}\text { View line I } \\
\text { (Fig. 10), moving } \\
\text { from the extension } \\
\text { of Palīdzìbas Street } \\
\text { along the south-west } \\
\text { coast of the Driksa } \\
\text { River to the ditch. }\end{array}$ & $\begin{array}{l}1 \\
8 \\
8 \\
0 \\
1 \\
8 \\
i \\
1\end{array}$ & $\begin{array}{l}\Xi \\
\stackrel{2}{1} \\
i\end{array}$ & $\begin{array}{l}\text { Visually high quality landscaped space. The view from the untreated, } \\
\text { degraded area at Jelgava Prison stretches across the River Driksa to } \\
\text { the landscaped Pasta Island with its bright concert hall construction. } \\
\text { The interior of the concert hall is not visible due to the distance. }\end{array}$ \\
\hline 10. & $\begin{array}{l}\text { View line J } \\
\text { (Fig. 11), following } \\
\text { Peldu Street in a } \\
\text { western direction to } \\
\text { the promenade. River } \\
\text { Lielupe. }\end{array}$ & 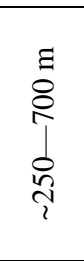 & $\begin{array}{l}\Xi \\
\stackrel{0}{ } \\
\stackrel{n}{i} \\
i\end{array}$ & $\begin{array}{l}\text { Initially, there is a severe disharmony consisting of a six-story, } \\
\text { high-rise business incubator building with gray concrete finish on the } \\
\text { right of Peldu Street, a relatively small, bright orange building on the } \\
\text { left, and a curved concert hall on the middle of the island. } \\
\text { Moving closer to the concert hall, as soon as the business incubator } \\
\text { building is behind you, the landscaping space gets balanced. } \\
\text { The interior of the concert hall is not visible due to the distance. }\end{array}$ \\
\hline
\end{tabular}

Interaction of landscape space and indoors under the influence of visual perception.

View points from indoor to urban landscape [created by the author, 2019]

\begin{tabular}{|c|c|c|c|c|}
\hline 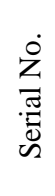 & $\begin{array}{c}\text { View marking and } \\
\text { direction }\end{array}$ & 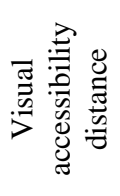 & $\begin{array}{l}\frac{3}{2} \\
\frac{3}{2} \\
\frac{1}{0} \\
0 \\
\frac{0}{60} \\
\frac{1}{4}\end{array}$ & Description of results \\
\hline 1. & $\begin{array}{l}\text { View point K } \\
\text { (Fig. 12), looking } \\
\text { from inside the } \\
\text { landscape area } \\
\text { north-west. }\end{array}$ & 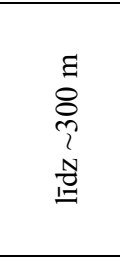 & $\begin{array}{l}\circ \\
\stackrel{\circ}{\wedge}\end{array}$ & 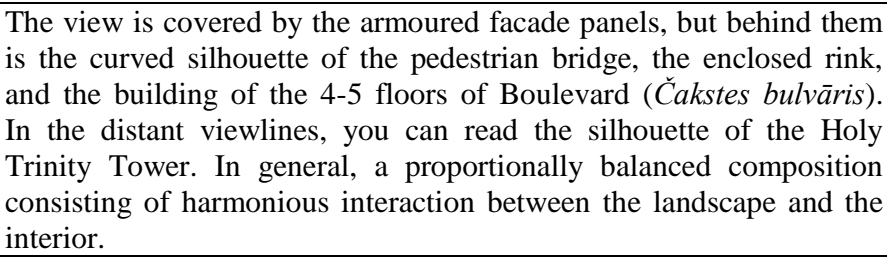 \\
\hline 2. & $\begin{array}{l}\text { View point } \mathbf{L} \\
\text { (Fig. 13), looking } \\
\text { from inside the } \\
\text { landscape area in } \\
\text { the north-east } \\
\text { direction, partially } \\
\text { shielded by } \\
\text { exposing facade } \\
\text { panels. }\end{array}$ & 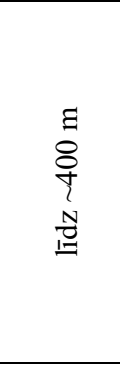 & $\begin{array}{l}\circ \\
\circ \\
\wedge\end{array}$ & $\begin{array}{l}\text { The open area of the facade shows the area of the Pärlielupe with the } \\
\text { right promenade of Lielupe, the relatively aggressive business } \\
\text { hatchery building and the scarlet orange-finished small-floor building } \\
\text { beside it. In spite of the considerable distance, the interaction between } \\
\text { landscape and indoor is a disco, caused by a strongly aggressive } \\
\text { accent, the existing business incubator building in its existing shape } \\
\text { and finish. The specific situation offers ample opportunities for } \\
\text { investors to build harmonious and high-value buildings on the right } \\
\text { coast of Lielupe, which would bring the necessary balance into the } \\
\text { building and landscape area as a whole. }\end{array}$ \\
\hline 3. & $\begin{array}{l}\text { View point } \mathbf{M} \\
\text { (Fig. 14), no an } \\
\text { indoor view of the } \\
\text { landscape area in } \\
\text { the south-west } \\
\text { direction is partly } \\
\text { obscured by } \\
\text { exposing facade } \\
\text { panels. }\end{array}$ & $\begin{array}{l}\Xi \\
8 \\
8 \\
? \\
\text { N } \\
\text { II }\end{array}$ & $\begin{array}{l}\stackrel{\circ}{\circ} \\
\stackrel{9}{v}\end{array}$ & $\begin{array}{l}\text { A view of the picturesque bend of the river Driksa, whose left coast is } \\
\text { adorned with a cluster of trees, hiding the visually chaotic building of } \\
\text { Soviet time, but a well-designed slope of the Mail Island with a lawn. } \\
\text { The picturesque silhouettes of sand sculptures stand out. Annually, } \\
\text { changing sculptures in the foreground, thanks to the traditional sand- } \\
\text { sculpture festival, make landscape space vibrant and interesting. } \\
\text { A strong accent with its building size is the nearby swimming pool } \\
\text { building on the opposite, right coast of the river Driksa. }\end{array}$ \\
\hline
\end{tabular}


Context of natural foundation and greenery in Interaction of landscape space and indoors.

View lines from landscape space to architecture [created by the author, 2019]

\begin{tabular}{|c|c|c|}
\hline 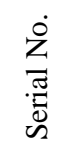 & $\begin{array}{c}\text { View } \\
\text { marking } \\
\text { and } \\
\text { direction }\end{array}$ & Description of results \\
\hline 1. & $\begin{array}{c}\text { View } \\
\text { line A } \\
\text { (Fig. 2) }\end{array}$ & $\begin{array}{l}\text { In the far-away view, plantations of large leaf trees and Coptic grasslands on the river slopes are } \\
\text { visible, supplemented with ornamental shrubs, grasses and bright plantations of summer flowers. On } \\
\text { the right side of the concert hall, ornamental plantings (hemerocallis citrina, spirraea x cinerea, abelia } \\
\text { mosanensis, weigela Florida, miscanthus sinensis, hemerocalis hybrida and others) in a rounded } \\
\text { triangular bed. In the close line of view, a bright accent in the lawn sector opposite the silhouette of the } \\
\text { concert hall - colours bright flower beds with seasonal flower (begonia) plantations created in a } \\
\text { stylised number of } 100 \text { forms, celebrating the Latvian State's hundredth year with red white flowers, } \\
\text { symbolically plotting the Latvian State flag. }\end{array}$ \\
\hline 2. & $\begin{array}{c}\text { View } \\
\text { line B } \\
\text { (Fig. 3) }\end{array}$ & $\begin{array}{l}\text { On the left side of the road, a cluster of large old willows that have managed to preserve during the } \\
\text { redevelopment of the Mail Island. The paving cover leads past a concert hall, in the foreground of the } \\
\text { Concert Hall, a spacious, well-fitted lawn in a grille and a rounded triangle-shaped boulder covering } \\
\text { with small plantations of ornamental trees. Rectangular containers in rust are installed at the concert } \\
\text { hall itself, resonating harmoniously with the elegant wooden structures of the concert hall. Seasonal } \\
\text { flowers and plants are growing in containers. For example, at the beginning of summer, they were } \\
\text { adorned with mottled pansies, and at the end of summer, bright pink peunias, white-faced (petunia) } \\
\text { and beautiful nuptials (coleus blumei "Wizard Velvet Red"). A bright and aesthetic color accent, } \\
\text { thanks to flower plantings, underscores the themes of the concert hall's entrance and merges the indoor } \\
\text { with landscape space harmoniously. }\end{array}$ \\
\hline 3. & $\begin{array}{c}\text { View } \\
\text { line C } \\
\text { (Fig. 4) }\end{array}$ & $\begin{array}{l}\text { The most powerful theme is the presence of the river, with the movement of water in its shapes the } \\
\text { diverse slopes of white sand grown in sectors by lawns. In view across the river, the concert hall is } \\
\text { partly covered by a swirl of small willows growing from a boulder area raised from the cobblestone, } \\
\text { divided parallel to the river into six small subgroups (salix acutilifolia } 9 \text { pieces, salix caspica } 24 \\
\text { pieces, } \\
\text { salix cinerea "Tricolor" } 6 \text { pieces, salix cinerea "Tricolor" ' } 4 \text { pieces, salix rosmarinfolia } 8 \text { pieces } \\
2 \text { subgroups) and helps to record the construction volume of the concert hall organically into the } \\
\text { landscape room. The chain of plants behind the moulding plant has been extended by the following } \\
\text { willow varietal plantings (salex rosmarinfolia } 8 \text { pieces, salix caspica } 8 \text { pieces, salix acutilifolia } 4 \\
\text { pieces, saliz acutifolia } 6 \text { pieces, saliz caspcia } 9 \text { pieces, salix rosmarinifolia } 12 \text { pieces) The extension is } \\
\text { divided by the carex (carex } 50 \text { pieces) plantings in a semi-circular bed. In general, the areas created by } \\
\text { the foliage of the trees could be even larger in the landscape area at a given moment. }\end{array}$ \\
\hline 4. & $\begin{array}{c}\text { View } \\
\text { line D } \\
\text { (Fig. 5) }\end{array}$ & $\begin{array}{l}\text { There are separate clusters of blacknaled trees (alnus glutinosa) on the right shore lawn of Lielupe, } \\
\text { and the long view line shows the large leaf trees on the Pasta island that have managed to be preserved } \\
\text { during reconstruction. A number of new plantings of trees and shrubs (salex, cornus, spiraea and } \\
\text { others) complement the clusters of plush trees. The strongest of the themes in the landscape space in } \\
\text { the particular pivot is Lielupe }\end{array}$ \\
\hline 5. & $\begin{array}{c}\text { View } \\
\text { line E } \\
\text { (Fig. 6) }\end{array}$ & $\begin{array}{l}\text { There is a harmonious landscape of the Lielupe water body and the Mail Island, which highlights } \\
\text { a picturesque sand beach in a particular direction, and the role of lawned waterfronts in integrating } \\
\text { exclusive architecture into the landscape. Landscape spaces are decorated separately with clusters of } \\
\text { leaf trees and a raised boulder area parallel to a river-growing surface of low willow (salix acutilifolia, } \\
\text { salix caspica, salix cinerea "Tricolor", salix rosmarinfolia). }\end{array}$ \\
\hline 6. & $\begin{array}{c}\text { View } \\
\text { line F } \\
\text { (Fig. 7) }\end{array}$ & $\begin{array}{l}\text { The front of the concert hall is decorated with plantations of ornamental shrubs (spiraea x cinerea, } \\
\text { weigela Florida, abelia mosanensis, hemerocallis citrina, hemerocallis hybrida, miscanthus sinensis } \\
\text { and others) in a rounded triangular bed and bright summer flower containers. The slope of a flat lawn } \\
\text { visually involves the waters of the river Driksa and the clusters of large trees growing on its left along } \\
\text { the accompanying line of views. In close viewlines, an occasional bed of ornamental shrubs and tree } \\
\text { plantings in a plump triangular lawn in front of a concert hall has been arranged in landscape spaces. } \\
\text { The most powerful color accent is the plantations of bright-flowering (petunia) and skaistnātru } \\
\text { (coleus), which are placed in rust-colored containers along the facade of the concert hall, underscoring } \\
\text { the wood structures of the concert hall in volume and design according to color. }\end{array}$ \\
\hline 7. & $\begin{array}{c}\text { View } \\
\text { line G } \\
\text { (Fig. 8) }\end{array}$ & $\begin{array}{l}\text { The architecture of the concert hall is underlined with bright accents produced by ointments (petunia) } \\
\text { and plants (coleus) adjacent to containers. The composition looks well against the backdrop of the } \\
\text { lawn growing on both shores of the river Driksa. Natural stone supporting walls used in indoor and } \\
\text { landscape spaces play a synthesizing role between indoor and landscape spaces. }\end{array}$ \\
\hline
\end{tabular}




\begin{tabular}{|c|c|c|}
\hline $\begin{array}{l}\dot{0} \\
\dot{z} \\
\dot{n}\end{array}$ & $\begin{array}{l}\text { View } \\
\text { marking } \\
\text { and } \\
\text { direction }\end{array}$ & Description of results \\
\hline 8. & $\begin{array}{c}\text { View line H } \\
\text { (Fig. 9) }\end{array}$ & $\begin{array}{l}\text { Clusters of large leaf trees and Coptic grasslands on both sides of the river Driksa are visible in } \\
\text { the far view. On the left side of the drivel, the steep slopes with grasslands are complemented by } \\
\text { ornamental shrubs, grasses and bright plantations of summer flowers. The right side of the drivel } \\
\text { is more mellowed, lined with lawn and garnished by a bright accent - colored flower beds with } \\
\text { seasonal flower (begonia) plantations created in a stylized number of } 100 \text { shapes, and arranged in } \\
\text { the red, white, red colors of the Latvian flag as a flag draped over the number. }\end{array}$ \\
\hline 9. & $\begin{array}{l}\text { View line I } \\
\text { (Fig.10) }\end{array}$ & $\begin{array}{l}\text { A degraded area saturated by arbitrarily growing trees and shrubs, with future opportunities, } \\
\text { opens a line of view across the river Drika to a concert-hall architecture that contrasts with its } \\
\text { light volume on the backdrop of landscape space and Mail Island lawn. On the left shore, } \\
\text { growing clusters of leaf trees on one side visually complement the building and record it more } \\
\text { organically in the landscape space. In the autumn, the landscape space provides additional golden } \\
\text { rusty shades. In a period when leaf trees lose leaves, the situation becomes more visually critical, } \\
\text { exposing a visually chaotic build-up of Soviet time. }\end{array}$ \\
\hline 10. & $\begin{array}{l}\text { View line J } \\
\text { (Fig. 11) }\end{array}$ & $\begin{array}{l}\text { The individual clusters of trees on both sides of Lielupe play an important role in the harmony } \\
\text { between architecture and landscape space, but their abundance is insufficient. In a period when } \\
\text { leaf trees and shrubs lose leaves, the situation becomes more visually critical. }\end{array}$ \\
\hline
\end{tabular}

Context of natural foundation and greenery in Interaction of landscape space and indoors.

TABLE 4

View points from indoor to urban landscape [created by the author, 2019]

\begin{tabular}{|c|c|c|}
\hline $\begin{array}{l}\dot{0} \\
\dot{z} \\
\dot{s}\end{array}$ & $\begin{array}{l}\text { View } \\
\text { marking and } \\
\text { direction }\end{array}$ & Description of results \\
\hline 1. & $\begin{array}{l}\text { View } \\
\text { point K } \\
\text { (Fig. 12) }\end{array}$ & $\begin{array}{l}\text { The presence of plants through shields is not clearly visible, but the presence of large leaf trees } \\
\text { on the coast of the river Driksa is clearly discernible and, with its volumes of green foliage, plays } \\
\text { an important role in the synthesis of harmonious landscape space and indoor space, as are the } \\
\text { growing, yet small, ornamental plantations of the concert hall. Autumn brings the warm shades } \\
\text { into the interior of the concert hall, changing the shades of foliage. The presence of bright } \\
\text { flowering petunia (petunia) and skaistnātru (coleus) plants, located in containers along the front } \\
\text { of the concert hall and juicy greens of forest wines (parthenocissus) rising along the grey stone } \\
\text { walls, are essential in the close viewlines, which ignite fire in reddish shades in the autumn. }\end{array}$ \\
\hline 2. & $\begin{array}{l}\text { View } \\
\text { point } \mathbf{L} \\
\text { (Fig. 13) }\end{array}$ & $\begin{array}{l}\text { In the distant line of views, a cluster of large leaf trees across Lielupe appears between the } \\
\text { building, which amplifies harmonies in existing buildings. The close viewlines are softened by } \\
\text { the low ball-shaped ornamental clusters of willow (salix acutilifolia, salix caspica, salix cinerea } \\
\text { "Tricolor", salix rosmarinfolia) drawn on the left coast of Lielupe near sand beach. In the fall, } \\
\text { the color palette of landscape space shifts from greens to golden-brown shades. }\end{array}$ \\
\hline 3. & $\begin{array}{l}\text { View } \\
\text { point } M \\
\text { (Fig. 14) }\end{array}$ & $\begin{array}{l}\text { A picturesque bend of the river Driksa in the confines of large leaf trees on one side and a tended } \\
\text { lawn on the other makes the particular pivot the most raucously harmonious thanks to plantations } \\
\text { of bright pink and purple petunia flowers (petunia) and (coleus) in rusty containers at the side } \\
\text { entrance of the concert hall. }\end{array}$ \\
\hline
\end{tabular}

Psycho-emotional nature of spatial synthesis under the influence of natural and artificial light distribution.

View lines from landscape space to architecture [created by the author, 2019]

\begin{tabular}{|c|c|c|}
\hline $\begin{array}{l}\dot{0} \\
\dot{z} \\
\dot{s}\end{array}$ & $\begin{array}{c}\text { View } \\
\text { marking and } \\
\text { direction }\end{array}$ & Description of results \\
\hline 1. & $\begin{array}{l}\text { View line A } \\
\text { (Fig. 2) }\end{array}$ & $\begin{array}{l}\text { Evaluation of compositional application of colour, light and shadow impacted by sunlight: } \\
\text { in the landscape area, the white coating of the concert hall works as a strong accent, reflecting in } \\
\text { the sunlight, thanks to the shape of its flat dome. The indoor area is in deep shadows and } \\
\text { in strong contrast with the light coating of the concert hall, without any communication with the } \\
\text { landscape area. In days when overcast, the structure of the concert hall is dimming, the shape of } \\
\text { the interior can be seen from the bridge. In the dark hours of the day: thanks to artificial lighting, } \\
\text { which consists of alternating colored headlights from the interior, the extensive coating of the } \\
\text { concert hall takes a colour-changing shape and brings the glow of the festival to the landscape } \\
\text { area. During the events, the visual presence of the interior of the concert hall is highly visible in } \\
\text { the landscape area, thanks to the special effects created by artificial lighting, creating harmonious } \\
\text { landscape spaces and indoor synthesis. }\end{array}$ \\
\hline
\end{tabular}




\begin{tabular}{|c|c|c|}
\hline $\begin{array}{l}\dot{z} \\
\dot{n}\end{array}$ & $\begin{array}{c}\text { View } \\
\text { marking and } \\
\text { direction }\end{array}$ & Description of results \\
\hline 2. & $\begin{array}{c}\text { View line B } \\
\text { (Fig. 3) }\end{array}$ & $\begin{array}{l}\text { Evaluation of compositional application of colour, light and shadow impacted by sunlight: he } \\
\text { landscape area breaks out a white coating part of a concert hall which, thanks to its curved form, } \\
\text { forms a powerful game of sunshine. Indoor in sunny weather is relatively in the shadows, but in } \\
\text { the particular direction, which is considered to be the main theme of the entrance, based on its } \\
\text { localisation in the landscape area, well-perceived indoor spaces, which significantly expands the } \\
\text { indoor landscape and increases the mutual impact of spaces to the extent that indoor and } \\
\text { landscape space flows freely into one another. Evaluation of the usage of visual accents created } \\
\text { by chiaroscuro play: the specific nature of the roof coating material in the light of sunlight } \\
\text { causes radiant reflections which act as an accent, strategically speaking in the theme landscape } \\
\text { area of the entrance of the concert hall. In days when overcast, the coating of the concert hall is } \\
\text { dimming, while more active communication is made by an indoor landscape area. In the dark } \\
\text { hours of the day:under the influence of artificial lighting, which consists of coloured indoor } \\
\text { spotlights, the extensive coating of the concert hall takes a colour-changing shape and brings a } \\
\text { glow to the landscape room. Dduring the events, the indoor concert hall is highly readable in the } \\
\text { landscape area, thanks to the special effects created by artificial lighting. }\end{array}$ \\
\hline 3. & $\begin{array}{c}\text { View line C } \\
\text { (Fig. 4) }\end{array}$ & $\begin{array}{l}\text { Evaluation of compositional application of colour, light and shadow impacted by sunlight: in the } \\
\text { landscape area of the landscape, the white volume of the concert hall stands out as it looks across } \\
\text { the water tank of Lielupe, which has been painted in sunny weather in the water. Indoor distance } \\
\text { and parking areas do not make communication with the landscape in practice. Evaluation of the } \\
\text { usage of visual accents created by chiaroscuro play: the specific nature of the roof coating } \\
\text { material in the light of sunlight causes a radiant reflectance that acts as an accent, strategically } \\
\text { highlighting the concert hall throughout the landscape area of Jelgava, Pasta island and the } \\
\text { relevant Lielupe fragment. In the days of overcast, the volume of the concert hall almost } \\
\text { converge with the landscape. In the dark hours of the day: thanks to the artificial lighting } \\
\text { resulting from changing coloured spotlights from the interior, the construction volume of the } \\
\text { concert hall is well visible from the Pärlielupe, bringing a strong accent and festive glow to the } \\
\text { landscape. During the events, what is happening in the interior of the concert hall with the } \\
\text { lighting of the spotlights is partially visible across the river. }\end{array}$ \\
\hline 4. & $\begin{array}{l}\text { View line D } \\
\text { (Fig. 5) }\end{array}$ & $\begin{array}{l}\text { Evaluation of compositional application of colour, light and shadow impacted by sunlight: } \\
\text { looking across the water tank of Lielupe, which is richly decorated in the water during the sunny } \\
\text { weather, the light construction volume of the concert hall reads well, despite its considerable } \\
\text { distance. Inindoor distance and parking areas do not create communication with landscape. } \\
\text { Evaluation of the usage of visual accents created by chiaroscuro play: the specific nature of the } \\
\text { roof coating material in the light of sunlight causes radiant reflections, acting as an accent, by } \\
\text { lifting the concert hall on the Isle of Mail and the corresponding fragment of Lielupe in the } \\
\text { background landscape area. In the days when overcast, the construction volume of the concert } \\
\text { hall almost converges with the landscape area. In the dark hours of the day: under the influence } \\
\text { of indoor artificial lighting, the construction volume of the concert hall is visible from the } \\
\text { Parlielupe and brings a joyous mood to the landscape area. During the events, due to the } \\
\text { highlighting of the spotlights, the distance from the interior of the concert hall is partly visual } \\
\text { across Lielupe. }\end{array}$ \\
\hline 5. & $\begin{array}{l}\text { View line } \mathbf{E} \\
\text { (Fig. 6) }\end{array}$ & $\begin{array}{l}\text { Evaluation of compositional application of colour, light and shadow impacted by sunlight: in the } \\
\text { landscape area Pärlielupe of the landscape, looking across the Lielupe water tank from the level } \\
\text { of view of the promenade (view line } \mathbf{E} \text { medium is several metres above the view line } \mathbf{C} \text { level of } \\
\text { views), in sunny times the games of shimmering bluegrass in the river water, but the most } \\
\text { powerful accent in the landscape area is the white concert hall construction. Volume. Indoor } \\
\text { space is under intense shading and communication with landscape space is practically not } \\
\text { developed. Evaluation of the usage of visual accents created by chiaroscuro play: the specific } \\
\text { nature of the roof coating material in sunlight and visual levels creates a radiant reflectance, } \\
\text { revealing a significantly larger coverage area of the concert hall than the view line } \mathbf{C} \text {, which acts } \\
\text { expressively as an accent, strategically highlighting the concert hall throughout the landscape. In } \\
\text { the days when the volume of the concert hall is overcast, the radiance of the landscape space is } \\
\text { lost. In the dark hours of the day: due to the artificial lighting resulting from changing coloured } \\
\text { spotlights from the interior, the construction volume of the concert hall is well perceived from } \\
\text { the Pärlielupe, bringing the landscape into the room a vibrant glow of color. During the events, } \\
\text { the illumination caused by the indoor spotlights of the concert hall is slightly visible from the } \\
\text { promenade. }\end{array}$ \\
\hline
\end{tabular}




\begin{tabular}{|c|c|c|}
\hline $\begin{array}{l}\dot{0} \\
\dot{z}\end{array}$ & $\begin{array}{c}\text { View } \\
\text { marking } \\
\text { and } \\
\text { directio } \\
n\end{array}$ & Description of results \\
\hline 6. & $\begin{array}{c}\text { View } \\
\text { line F } \\
\text { (Fig. 7) }\end{array}$ & $\begin{array}{l}\text { Evaluation of compositional application of colour, light and shadow impacted by sunlight: in the } \\
\text { landscape, behind sand sculptures, the construction of a concert hall with a relatively thin white- } \\
\text { shimmering part of the coating, which, thanks to its curved shape, forms a game of sunshine. From } \\
\text { the outermost viewpoint, the indoor area is not visible, but when approaching the concert hall, the } \\
\text { indoor area is in the shadows at sunny times, but the landscape space behind the concert hall is also } \\
\text { well perceived in the concrete direction through the indoor area, which significantly expands the } \\
\text { indoor landscape and increases the mutual impact of the rooms to the extent that the indoor and } \\
\text { landscape space flows freely the other one. Evaluation of the usage of visual accents created by } \\
\text { chiaroscuro play: the specific nature of the roof coating material in the light of sunlight causes } \\
\text { radiant reflections, acting as an accent, strategically highlighting the construction volume of the } \\
\text { concert hall in the landscape area. In days when overcast, the coating of the concert hall is } \\
\text { dimming, while more active communication is made by a landscape space with a landscape space } \\
\text { behind the concert hall, looking through the interior. In the dark hours of the day: under the } \\
\text { influence of artificial lighting consisting of indoor spotlights, the visual visible band of the curved } \\
\text { coating of the concert hall shall obtain a colour-altering silhouette. }\end{array}$ \\
\hline 7. & $\begin{array}{c}\text { View } \\
\text { line G } \\
\text { (Fig. 8) }\end{array}$ & $\begin{array}{l}\text { Evaluation of compositional application of colour, light and shadow impacted by sunlight: in the } \\
\text { urban landscape area, the white concert hall coating works as a strong accent, looking across the } \\
\text { river Driksa to the Pasta island, which, thanks to its flat-dome form, reflects the sun-light game. } \\
\text { The indoor area is heavily shaded in sunny weather, but it is partly connected with landscape space. } \\
\text { Evaluation of the usage of visual accents created by chiaroscuro play: the roof coating creates a } \\
\text { gleaming reflection which acts as a high accent by striking the construction volume of the concert } \\
\text { hall on the visual extension of Raina (Raina) Street. When overcast, the coating of the concert hall } \\
\text { becomes visually inactive, but there is a relatively more active interaction between indoor and } \\
\text { landscape spaces. In the dark hours of the day: with artificial lighting, the construction volume of } \\
\text { the concert hall becomes an active centre of Raina Street. The interior of the concert hall is also } \\
\text { visually exposed to the landscape area during events, bringing urban festivals outside the borders of } \\
\text { the concert hall across the river Driksa on Čakstes Boulevard and partly Raina Street. }\end{array}$ \\
\hline 8. & $\begin{array}{c}\text { View } \\
\text { line H } \\
\text { (Fig. 9) }\end{array}$ & $\begin{array}{l}\text { Evaluation of compositional application of colour, light and shadow impacted by sunlight: in future } \\
\text { views, the structure of the concert hall is barely visible behind the elegant curvature of the } \\
\text { "Mitavas" Bridge, moving closer to the concert hall along the Bridge, a strong accent entering the } \\
\text { landscape area consisting of the expressive air-moon games of the large-span roof of the concert } \\
\text { hall. The indoor area is shaded in sunny weather, and the overview is covered by awny wind panels. } \\
\text { Evaluation of the usage of visual accents created by chiaroscuro play: the roof coating of the } \\
\text { concert hall creates a shimmering reflectance which acts as an accent on the well-fitted Cakstes } \\
\text { boulevards, the reflection of the waters of the river Driksa in the sun and the background of the } \\
\text { Pasta island. When overcast, the volume of the concert hall and the indoor landscape area are } \\
\text { visually passive. In the dark hours of the day: with artificial lighting, the construction volume of the } \\
\text { concert hall becomes one of the main sites illuminated in the landscape area alongside the Railway } \\
\text { Bridge, the "Mitava" Bridge, the "Silva" Tea House, the lighthouse and other highlighted objects } \\
\text { on land and water. The interior of the concert hall is also visually exposed to the landscape area } \\
\text { during events, bringing festive lights outside the borders of the concert hall across the river Driksa } \\
\text { on the Cakstes Boulevard. }\end{array}$ \\
\hline 9. & $\begin{array}{c}\text { View } \\
\text { line I } \\
\text { (Fig. 10) }\end{array}$ & $\begin{array}{l}\text { Evaluation of compositional application of colour, light and shadow impacted by sunlight: the area } \\
\text { overgrown by trees and shrubs allows only visual reception of the curved light concert hall } \\
\text { construction volume, which rises across the river in the Pasta island landscape area thanks to } \\
\text { sunlight. The indoor is not visible. Evaluation of the usage of visual accents created by chiaroscuro } \\
\text { play: the roof coating of the concert hall creates a luminous reflectance that glinks in the distance } \\
\text { behind the trees. Ehen overcast, the indoor is not visible. In the dark hours of the day: with artificial } \\
\text { lighting, the construction volume of the concert hall becomes an accent in the landscape area. } \\
\text { The interior of the concert hall is not visually visible due to its proximity and distance. }\end{array}$ \\
\hline 10. & $\begin{array}{c}\text { View } \\
\text { line J } \\
\text { (Fig. 11) }\end{array}$ & $\begin{array}{l}\text { Evaluation of compositional application of colour, light and shadow impacted by sunlight: on the } \\
\text { road of Peldu and looking across Lielupe, the illuminated white building volume of the concert } \\
\text { hall's sunlight games is visual, despite the sheathing of buildings in the landscape of Pärlielupe. } \\
\text { Indoor distance and shading means that communication with landscape space is practically not } \\
\text { developed. Evaluation of the usage of visual accents created by chiaroscuro play: the glow of the } \\
\text { roof coating in the sunlight significantly reinforces concert halls in the dominantly landscape area } \\
\text { on the visual extension of the Peldu street. In the days when the volume of the concert hall is } \\
\text { overcast, the radiance of the landscape space is lost. In the dark hours of the day: thanks to the } \\
\text { artificial lighting resulting from changing coloured spotlights from the indoor area, the construction } \\
\text { volume of the concert hall is well-perceived from the trajectory of Peldu Street as a coloured urban } \\
\text { accent between the lights of the Lielupe Bridge and the Railway Bridge. }\end{array}$ \\
\hline
\end{tabular}


Psycho-emotional nature of spatial synthesis under the influence of natural and artificial light distribution.

View points from indoor to urban landscape [created by the author, 2019]

\begin{tabular}{|c|c|c|}
\hline 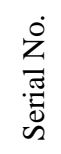 & $\begin{array}{c}\text { View } \\
\text { marking } \\
\text { and } \\
\text { direction }\end{array}$ & Description of results \\
\hline 1. & $\begin{array}{l}\text { View } \\
\text { point K } \\
\text { (Fig. 12) }\end{array}$ & $\begin{array}{l}\text { Evaluation of compositional application of colour, light and shadow impacted by sunlight: in the } \\
\text { particular direction, the direct sunlight affects the indoor areas most in the morning and evening } \\
\text { hours, from which the skylines of the urban buildings are particularly drawn in colors in the } \\
\text { expressive setting of the sun-induced harmony landscape and indoor interaction. Acoustic panels } \\
\text { fortified in different links to the elegant curved wooden structures of the concert hall division under } \\
\text { sunlight form a unique and harmonious symphony of air and colors covering the curved ceilings of } \\
\text { the large format and reflecting in grey concrete floors and stone supporting wall planes. Evaluation } \\
\text { of the usage of visual accents created by chiaroscuro play: sunlight playing plays on the adjacent } \\
\text { surface of Driksa water reflected in acoustic shields on the ceiling of the concert hall, transforming } \\
\text { the room visually from stilled material into a living lightly shimmering organism. In days when the } \\
\text { interaction between the overcast, indoor and landscape area is fading. In the dark hours of the day: } \\
\text { thanks to the artificial lighting caused by the specialised effects of headlights in the indoor area, the } \\
\text { landscape space is gradually fading out of sight in front of the activities on the stage as the sun rises } \\
\text { and darkness fades. The artificial lighting of the urban environment is shining, which complements } \\
\text { what is happening in the indoor environment. }\end{array}$ \\
\hline 2. & $\begin{array}{c}\text { View } \\
\text { point L } \\
\text { (Fig. 13) }\end{array}$ & $\begin{array}{l}\text { Evaluation of compositional application of colour, light and shadow impacted by sunlight: in the } \\
\text { light of sunlight, the landscape area enters very actively visually into an indoor area under } \\
\text { comparative shading. Grey concrete floors and cobblestones, thanks to the shading created by the } \\
\text { roof cover structures, produce a weather-changing adornment of light areas that enliven the interior } \\
\text { by sunlight. Evaluation of the usage of visual accents created by chiaroscuro play: sunscreen } \\
\text { coating with light-transmitting properties becomes a high light accent, accompanied by sun-induced } \\
\text { variable light accents in all planes of the room. In the days when the indoor and landscape } \\
\text { interaction of the concert hall is overcast, the brightness of colors is lost, but, thanks to the light- } \\
\text { transmitting capabilities of the cover material, it is nevertheless a 3-D lightness. In the dark hours of } \\
\text { the day: thanks to the artificial lighting resulting from changing coloured spotlights from the indoor } \\
\text { area, the construction volume of the concert hall is well-perceived from the trajectory of Peldu } \\
\text { Street as a coloured urban accent between the lights of the Lielupe Bridge and the Railway Bridge. } \\
\text { Artificial lighting of the Pasta island is a good complement to what is happening in the interior. }\end{array}$ \\
\hline 3. & $\begin{array}{c}\text { View } \\
\text { point M } \\
\text { (Fig. 14) }\end{array}$ & $\begin{array}{l}\text { Evaluation of compositional application of colour, light and shadow impacted by sunlight: the sun } \\
\text { communicates with the interior by sunbathing it. In the particular direction, as in point } \mathbf{M} \text {, the } \\
\text { acoustic panels on the elegant curved wooden structures of the concert hall division, in the light of } \\
\text { sunlight, are a unique pattern of light and colors adorning the curved ceiling and reflecting in floors } \\
\text { and wall planes. Evaluation of the usage of visual accents created by chiaroscuro play: sunlit areas } \\
\text { create a live indoor playing of light; In days of overcast, more active indoor landscape space with } \\
\text { the curved silhouette of the river Driksa. In the dark hours of the day: landscape and indoor } \\
\text { communication on distant viewlines fades with the onset of darkness, as the visible chunk of the left } \\
\text { coast of Driksa cannot yet be proud of sufficient illumination. Thanks to the highlighting of the } \\
\text { Pasta island, there is a little bit of the artistic presence of sand sculptures in the interior. }\end{array}$ \\
\hline
\end{tabular}

\section{Conclusions}

Jelgava's urban landscape space has become richer in 2019 with the original, modern construction of large-span curved, glued wooden structures - an open-air concert hall called "Mìtava", underscoring the spotlight of harmonious landscape spaces and indoor interaction today. The stylized snail-like structure of a concert hall covered with a milkish, light-reflecting membrane brings a new dominant between two rivers into the existing Pasta island and adjacent areas, visually arranging the urban landscape space. The arrangements and buildings of Chacste Boulevard ( $\breve{C a k s t e s}$ bulvāris) with the silhouette of the Holy Trinity Tower in the background, the new pedestrian bridge "Mìtava" and a balanced volume of plantings provide visual

and high-quality tendencies. Visual harmony is hampered by a large temporary tent long on the left side of the concert hall, the degraded areas of the Pasta island on the left coast of Lielupe, the aggressive construction of the business incubator on the right of Lielupe and the left-side Jelgava prison area on the left side of Driksa river, the chaotic building of Soviet time alongside it and the outdated facade of the swimming pool directed against the Driksa river. The interior of the concert hall communicates delicately with the landscape area if the entrance shields are both raised and lowered. Visual-quality interaction between indoor and landscape spaces is formed in the direction of Chacste Boulevard, as opposed to the direction of Parlielupe. 
The most visually powerful theme of the natural base is the river water movement, the diverse white sand slopes in shapes, and the balanced size and diversity of plants. The presence of large leaf trees on the shores of Driksa river and Lielupe, with their volumes of green foliage, plays an important role in the synthesis of harmonious landscape space and indoor spaces, as do the ornamental plantations growing in the foreground of the concert hall. Autumn brings the warm shades into the interior of the concert hall, changing the shades of foliage. Essential in the close viewlines are the presence of bright flowering petunia and (coleus) plants located in containers along the front of the concert hall and the twists of forest wines (parththenocissus) rising along the grey stone walls, which ignite fire in reddish shades in the autumn. The close viewlines are softened by the low ball-shaped ornamental willow (salix acutilifolia, salix caspica, salix cinerea "Tricolor", salix rosmarinfolia) clusters on the left shore of Lielupe. In the fall, the color palette of landscape space shifts from greens to golden-brown shades, dynamically enriching the space.

In the landscape room, the white coating of a concert hall works like a strong accent, reflecting the sun-influenced game in a flat dome shape, while the interior is in deep shadows and in strong contrast with the bright coating of the concert hall, without having to communicate with the landscape. As the sun relieves, indoor space will be proportionally reinforced, creating a room that interrupts with the landscape. The specific nature of the roof coating material in sunlight causes a gleaming blinding reflection that acts as a visual accent of a large area, strategically highlighting the construction volume of the concert hall throughout the landscape of Jelgava, Mail Island and the relevant Lielupe fragment, while the indoor shapes become visible on days when the overcast, concert-hall structure is dimming. In the dark part of the day, thanks to changing artificial lighting consisting of colored lights on the backs of the building-bearing poles, the extensive coating of the concert hall takes a colour-changing shape. During the events, visual visual visuals in the indoor area of the concert hall can be seen in the landscape area, thanks to the special effects created by artificial lighting, creating harmonious landscape spaces and indoor synthesis.

Direct sunlight affects the indoor areas most in the morning and evening hours, which is particularly driven behind the silhouettes of the urban buildings in colors in the expressively setting sun-induced harmony landscape space and indoor interaction. The acoustic panels fortified in various twists, on the curved wooden structures of the concert hall division, under the influence of sunlight, form a unique and harmonious pattern of light and colors covering the curved ceilings of the large format and reflecting in gray concrete floors and stonesupported wall planes. The sun-generated playing of light on the adjacent surface of Driksa water reflected in acoustic shields on the ceiling of the concert hall, transforming visual space from stillness into a living lightly shimmering organism. The roof coating having light-penetrating properties becomes, in the sunlight, a great bright accent, accompanied by changing light accents from the sun in all rooms in planes. On days when the interaction between the overcast, indoor and landscape space is losing shine. Thanks to the artificial lighting created by the specialised effects of headlights in the interior, the landscape space gradually fades out of sight in front of the activities on the stage, the artificial lighting of the drilling environment, which perfectly complements what is happening in the interior.

The realisation of an artistically stylistic concept in an open-air concert hall called "Mìtava", downstream to an existing landscape space, is generally considered to be a valuable contribution to a urban environment. The concrete example underlines the importance of successful interdisciplinary cooperation in harmonious landscape and indoor interaction, opening up new opportunities in the future.

\section{References}

1. Arhitektūra un kultūrpolitika Latvijā [tiešsaiste]. Latvijas arhitektūras politika 2020 [skatīts 7.02.2020]. https://www.latarh.lv/f/Latvijas\%20arhitekturas\%20politika\%202020_pa\%20lapam.pdf

2. Baukultur un Davosas deklarācija [tiešsaiste]. Latvijas arhitektūras politika 2020 [skatīts 7.02.2020]. https://www.latarh.lv/f/Latvijas\%20arhitekturas\%20politika\%202020_pa\%20lapam.pdf

3. Brīvdabas koncertzāle "Mītava" atklāta [tiešsaiste]. Jelgavas pilsēta pašvaldības iestāde Kultūra [skatīts 24.01.2020]. [http://kultura.jelgava.lv/article/brivdabas-koncertzale-mitava-atklata

4. Grietēna, A. Ainavu telpas un iekštelpas mijiedarbe Latvijas izglītības un mākslas ēku arhitektūrāa [tiešsaiste]. Promocijas darba kopsavilkums Arhitektūras zinātniskā grāda (Dr. arch.) iegūšanai ainavu arhitektūras apakšnozarē, LLU [skatīts 24.01.2020]. https://llufb.llu.lv/dissertation-summary/landscapearchitecture/Aija_Grietena_prom_ darba_kopsavilkums2019_LLU_VBF.pdf

5. Grietēna, A.; Ziemelniece, A.; İle, U. The interactivity of the landscape space and interiors in the architecture of the Latvian education and art buildings of the $20^{\text {th }} / 21^{\text {st }}$ century. Landscape Architecture and Art. 2017, V 11, p. 15-22.

6. Ieraksti 2019.gada 15. jūnijs [tiešsaiste]. SIA Igate Būve [skatīts 27.01.2020]. https://www.facebook.com/Igate Buve/posts/1475287615946942/

7. Mìtava, brīvdabas estrāde [skatīts 11.09.2019]. https://www.google.com/maps/search/koncertzale+m\%C4\% ABtava/@56.652107,23.7247161,804m/data=!3m2!1e3!4b1?hl=en 
8. Noskaidroti konkursa "Ilgtspējība arhitektūrā, būvniecībā, dizainā 2019" uzvarētāji [skatīts 27.01. 2020]. https://abc.lv/raksts/noskaidroti-konkursa-ilgtspejiba-arhitektura-buvnieciba-dizaina-2019-uzvaretaji-b692fff8fe

9. Ozoliṇ̌s, A. Ar lapotni debesīs. Kāpēc Latvijā baidās būvēt daudzstāvu ēkas no koka [tiešsaiste]? LA.LV. [skatîts 31.01.2020]. https://www.la.lv/koku-baidas-celt-uz-augsu-koka-ekas

10. Pazinoti konkursa "Latvijas Būvniecības gada balva 2014" uzvarētāji [skatīts 7.02.2020.]. https://abc.lv/raksts/pazinoti-konkursa-latvijas-buvniecibas-gada-balva-2014-uzvaretaji

11. Skinner P. Reflections on Inside-Outside Space [cited 11.09.2020.]. https://espace.library.uq.edu.au/ data/UQ_3545/insideoutsidetext.pdf?Expires=1548959072\&Signature=ZEAsLcwvV389BveVI5DV5RxFiSqTzRu4FTzJjLr4ErwSSV1T0jcJgbrsQA M8OpmPpvUyKaQVEgTIdVYEhFyKwTcBHvO 1ogSyYf05S11NjIW09If6EtCrt pYXHM7hDXr1PXhMRUXPZCPmqKK0YN739mQYS0VDqM84oQfP5YnA3xpbirvNetBWF273ISZ5qWev vXEmgGtRS1LodavRbNiPTjjFLG4s0mnxcJcpxvOCDI4rYc CbKoUuGs-6pWaEGbFkjtHDW70WuZi7 fOchhJYCB02Ma1KBiEBq3rVgDkZI7j3gPLwDPEC7bWXUtBq2PmYK0x7ws66waIHWuvA_\&Key-Pair-Id=APKAJKNBJ4MJBJNC6NLQ.

12. Strautmanis, I. Latviskā telpa. Rīga, RTU izdevniecība, 2011, 157 lpp.

13. Zigmunde, D. Estētiskās kvalitātes kritēriji urbanizētas ainavas izpētē. LLU Raksti 25 (320), Jelgava, 2010, 1.-2. lpp.

AUTHOR:

Aija Grietēna, Dr. arch., certified architect at firm Grietēns Arhitekti. Field of research: interaction of landscape space and indoors in architecture. E-mail: aijagrietena@gmail.com

Kopsavilkums. Meklējot līdzsvarojošos faktorus vides veidošanas mākslā starp arhitektūru, ainavu arhitektūru un interjeriem, kas nepieciešami starpdisciplinārā sadarbībā balstītas plānošanas uzlabošanai un vides psihoemocionālās kvalitātes celšanai, tiek turpināts pētījums par ainavu telpas un iekštelpas mijiedarbi, izmantojot salīdzinošās analīzes un induktīvās uzziņas metodes.

Latvijas mērogā jaunas, plašas 21. gadsimta tehnoloǵiskas iespējas koka būvkonstrukciju projektēšanā un ražošanā materializējušās brīvdabas koncertzāles "Mītava" arhitektūrā, kas 2019. gadā uzbūvēta Pasta salā, Jelgavā. Unikālas, lielu laidumu, liekti, līmētas koksnes vienlaidu jumta konstrukcija līdz 60 m, atgādina Lielupes krastā izskalotu gliemežvāku. Oriǵinālas koka būvkonstrukcijas pavērušas jaunas iespējas ainavu telpas un iekštelpas mijiedarbei, veidojot plašu, savdabīgu telpisku sintēzi.

Mākslinieciski stilistiskās koncepcijas realizācija brīidabas koncertzālē "Mītava", kas pakārtota esošajai ainavu telpai un papildināta ar atbilstošiem apstādījumiem, uzskatāma par vērtīgu pienesumu urbānā pilsētvidē Baltijas mērogā, pateicoties unikālu lielu laidumu liekti līmētu koka konstrukciju izmantojumam oriǵinālā arhitektūrā un harmoniskai ainavu telpas un iekštelpas mijiedarbei. Konkrētais piemērs pasvītro veiksmīgas starpdisciplinārās sadarbības nozīmi harmoniskas ainavu telpas un iekštelpas mijiedarbē. 